\title{
Analyzing Financial Factors to Improve Production and Business Efficiency
}

Submitted 18/10/19, $1^{\text {st }}$ revision 23/12/19, $2^{\text {nd }}$ revision 11/01/20, accepted 01/02/20

\author{
N.V. Huan ${ }^{1}$, N.T. Hang ${ }^{2}$
}

Abstract:

Purpose: The paper's aim is to analyze the business and production activities of an enterprise on researching and analyzing financial situation and factors affecting financial indices. On this basis, the article gives a panoramic view of the current financial situation and offers effective solutions to manage finances.

Design/Methodology/Approach: In this article we have conducted a survey and analyzed the reality of the financial situation of TISCO in the period of 2016-2018. On that basis, the authors proposed an effective financial management solution for TISCO.

Findings: On the basis of analyzing the advantages of an enterprise financial factor analysis methods the paper took advantage of the strengths of the existing method combined with testing analysis, descriptive statistics and charts to assess the current situation and give general and specific overview of the financial situation of large Vietnamese enterprises such as TISCO. The paper suggests a solution for the corporate restructuring of TISCO.

Practical implications: Based on the methods of financial factor analysis combined with descriptive statistical analysis the article has been applied to analyze and assess the actual financial situation in large enterprises in Vietnam and make recommendations on corporate financial management to help businesses operate more effectively.

Originality/Value: The authors have conducted research and applied the analysis of the financial reality of a large enterprise that is now in a period of great loss. This article gives an accurate, honest and objective assessment of the reality of TISCO making effective recommendations on corporate financial management.

Keywords: Financial indices, TISCO-Thai Nguyen Iron and Steel Joint Stock Company.

JEL Codes: M10, M11, M21.

Paper Type: Research Paper.

\section{Acknowledgments:}

In order to complete this paper, the authors would like to thank Thai Nguyen Iron and Steel Joint Stock Company for their support in discussing and providing necessary information related to the article, thank SHB Commercial Joint Stock Bank for supporting the review of the paper and financial results for the authors in the research process. The authors also thank the Faculty of Economic Information Systems, Thai Nguyen University of Information and Communication Technology.

\footnotetext{
${ }^{1,2}$ Thai Nguyen University of Information and Communications Technology, Viet Nam, Economic Information Systems, nvhuan@ictu.edu.vn, nthang@ictu.edu.vn
} 


\section{Introduction}

Thai Nguyen Iron and Steel Joint Stock Company (TISCO) is a leading company in Vietnam, operating in the field of iron and steel. TISCO is the state joint stock company. In recent years, the field of production and business activities of the company has tended to decline in all aspects from revenue, equity, total assets, number of workers, (TISCO Financial Statement, Viet Nam 2016-2018), currently having big debts, with debts of trillions of dong in Vietnam. In order to analyze and accurately assess the situation of production and business activities of TISCO the article proposes effective solutions to overcome the difficulties of the company.

For any business in the world, one of the top concerns is the financial issue of the business. Corporate finances are numbers that tell us about the existence and growth of every business. Therefore, in the course of development, production and business activities, each enterprise needs to regularly monitor, follow up and master accurately about its financial situation (Curtis and Thalassinos, 2005).

In fact, each enterprise's way of capturing and monitoring its financial situation in its own way and this depends on many criteria such as: indicators of financial structure analysis, ability to solvency, profitability etc., among these indicators profitability indicators are always of special interest to those who want to know if the business they are interested in is profitable or not so that they can offer them the best decision, in order to improve the Company's production and business performance. Proposing to the company to be more proactive in strengthening maintenance, expanding business operations, reducing unnecessary costs, improving the efficiency of using resources, solutions to overcome difficulties, bringing revenue and profits soaring every year (Solovjova et al., 2018).

\section{Literature Review and Legislative Background}

To analyze the financial situation of businesses, there are many different methods such as comparison method, ratio method, balance method, Dupont method (Boyd, 1989; Sheela and Karthikeyan, 2012; Maranville and Liesz, 2008) in which the Dupont method is commonly used to analyze the profitability of businesses. Profitability is one of the important capabilities that any business needs to pay attention to. The question of this paper is to study the theoretical basis of analyzing the financial situation of enterprises, the criteria to assess the financial situation of enterprises such as ROE, ROA (Heikal and Khaddafi, 2014: Rupeika-Apoga and Saksonova, 2018). Thereby, using the Dupont analysis model to propose and analyze the factors affecting ROE, ROA and impact on the financial situation of the business. From there, the results of the article will help managers and administrators to get useful information, an objective view of the financial situation of their businesses, get an accurate view and support to bring make accurate and timely decisions to ensure businesses are profitable (Kourtis et al., 2019; Suharno and Dini, 2018). 
The paper focuses on researching and analyzing financial situation, analyzing factors affecting ROE, ROA and impact on the financial situation of TISCO, secondary data for the period 2017-2018, collected from the financial statements of the company TISCO (TISCO Financial Statement, Viet Nam 2016-2018). The results of the Dupont model trial study will be the basis for proposing some solutions to improve the production and business performance of TISCO.

The object of the study is the parameters in the financial statements of TISCO Company. Specifically, the figures on total assets, net revenue, profit after tax, equity and the relationship between the parameters in the analysis of the rate of return on assets (ROA) and the fertility rate return on equity (ROE). The approach of the paper is to study the figures in the financial statements, communicate with the managers of TISCO, analyze, synthesize and evaluate the financial situation of the company. In particular, the authors talk with a number of experts on economics and business restructuring to get the best solutions.

\section{Data and Research Methods}

The method used in the study is the Dupont model (Prendergast, 2006), which is used to analyze a firm's profitability with traditional effective management tools. The Dupont model integrates many elements of the income statement with the balance sheet. The Dupont Model was invented by Donaldson Brown in 1914, an electrical engineer who joined the financial department of the giant chemical company Dupont. A few years later, Dupont acquired 23 percent of General Motors (GM) shares, which led him to work at GM to reorganize the car's financial chaos.

This was probably the first large-scale restructuring in the US at the time. According to Alfred Sloan, former president of GM, much of GM's success later contributed significantly to Brown's planning and control system, which later became known as the Dupont model. The success of GM has made the Dupont model popular among many corporations in the United States and widely used in financial analysis. The Dupont model shows the relationship between the composite indicator reflecting the profitability of an enterprise such as Return on Assets (ROA) and Return on Equity (ROE) although there is a causal relationship with each other.

Return on Total Asset shows the efficiency of asset used in business (Prendergast, 2006). This is a pretty comprehensive indicator of business performance, showing how many of the assets used in a business can generate so much profit. The magnitude of this indicator is high in terms of efficiency in the use of enterprise assets. The Dupont model is as follows:

$\mathrm{ROA}=$ Profit after tax/Net revenue * Net revenue/Average assets;

$\mathrm{ROA}=$ Net profet margin $(\mathrm{ROS}) *$ Number of assets turnover; 
From the above model, we can see that the return on ROA is influenced by two factors of profitability on turnover and asset efficiency. Profitability on revenue or Return on Sales (ROS) indicates the ratio of profit after tax to sales. This factor is important for current and prospective owners assessing the profitability and future prospects of the business. This indicator is also of interest to business executives for direct expression of cost control - the result of management decisions. Asset utilization or total asset turnover, if multiple asset cycles, will represent a fast turnover of assets and a good mobilization of firm assets to generate revenue for the business. Investors, suppliers are very interested in this indicator. Therefore, managers often have to seek business measures to increase the total turnover of the business assets. That is to maximize revenue on the basis of the level of assets assigned management and use.

Dupont model research found that businesses want high ROA, so they need to be profitable with high turnover and high asset utilization. ROA is a fundamental tool for managing and utilizing enterprise resources. Return on Equity is an important component of an enterprise's capital and owners are eager to capitalize on the high cost of using it to enrich themselves. To measure efficiency equity analysts often use the ROE-Return on Equity (Prendergast, 2006). This index shows how much equity a shareholder pays out how much profit is made, the ROE is not only interested for the investor, but also to the joint stock companies. Listed on the stock market because this is the norm often used by investors to compare the stocks of the same industry on which to make a decision to buy shares. Often, the ROE of a business is higher than that of other enterprises. However, ROE is not always a good indicator because although ROE is high business is at great risk, this is not what shareholders want. To better understand the factors that affect ROE, analysts often use the Dupont model to analyze it. The Dupont model is as follows:

ROE=Profit after tax/Net revenue*Net revenue/Total average assets*Total average assets/Equity average

ROA $=$ Net profet margin $(\mathrm{ROS}) *$ Number of total assets turnover*Asset/Equity ratio

With this approach, a clear explanation for the volatility of the ROE can be explained. For ROE to rise, net margins, increased total asset turnover and financial leverage are needed. ROS and total asset turnover are two positive factors impacting ROE as these indicators demonstrate the profitability and efficiency of enterprise asset utilization. The equity-to-equity ratio is a double-edged sword, the positive side of which is financial leverage, and the negative side is the financial risk. From a financial leverage angle, this factor will increase ROE. However, the high equity-todebt ratio represents a significant proportion of the total capital of an enterprise, which means that the business is exposed to large financial risks. Therefore, when analyzing the effectiveness of the use of equity, we need to carefully consider each factor affecting the ROE. 
Thus, ROE and ROA are important indicators to assess the financial situation of enterprises. Through the Dupont model we can see the factors that affect the two indicators and affect the financial situation of the business. This will help managers to make informed decisions in a timely manner.

For the empirical part of the paper we have collected data from TISCO for the period of 2016-2018 with the following main criteria: Total assets is the total value of all the existing assets of the company up to the time of making the report; Equity capital is the capital owned by the company. Equity capital usually includes initial capital, undistributed profits, new shares and company funds; Net revenue is the total turnover earned by the company; After-tax profit is the total amount of net profit collected by the company in the year (Table 1):

Table 1. Basic financial status of TISCO 2016-2018 (Unit: Million Vietnam Dong)

\begin{tabular}{lccc}
\hline Targets & Year 2016 & Year 2017 & Year 2018 \\
\hline Total assets & 11.147 .477 & 9.939 .887 & 10.572 .664 \\
Equity & 2.785 .057 & 1.888 .651 & 1.871 .055 \\
Net revenue & 8.578 .150 & 9.725 .418 & 10.934 .737 \\
Profit after tax & 205.818 & 100.174 & 28.940 \\
\hline
\end{tabular}

Source: TISCO's fiscal year report 2016-2018.

\section{Results}

In this research, the paper presents the research results on the financial situation analysis of TISCO based on Dupont model along with ROA, ROE, ROS, total asset turnover, autonomy ratio key and data collected are based on Table 1 above.

Figure 1. Graph of TISCO financial status

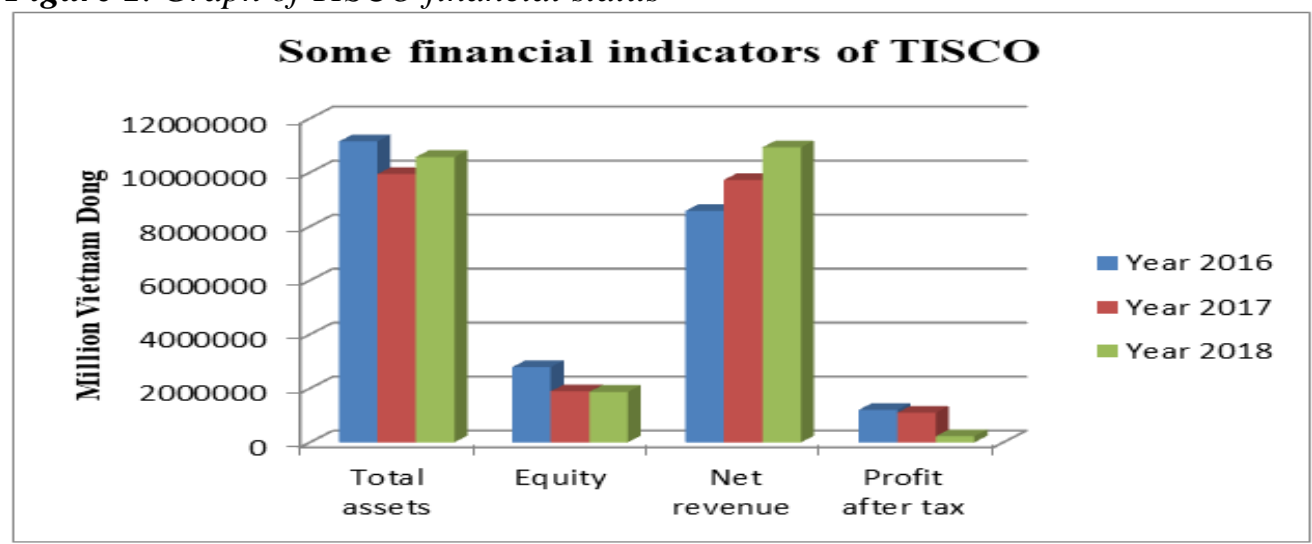

Source: TISCO's fiscal year report 2016- 2018.

Figure 1 shows that in the period of 2016-2018, total assets in 2016 was 11,147,477 Million Vietnam Dong, while by 2018 reduced to 10,572,664 Million Vietnam Dong. Equity in 2016 was 2,785,057 Million Vietnam Dong, while by 2018 reduced to $1,871,055$ Million Vietnam Dong. Profit after tax in 2016 was 205,818 Million 
Vietnam Dong, while in 2018 reduced to 28,940 Million Vietnam Dong. Net sales increased but not significantly in2016 was 8,578,150 Million Vietnam Dong, going up to $10,934,737$ Million Vietnam Dong in 2018. This shows that in the years from 2016 to 2018, TISCO did not grow, TISCO's production and business activities decreased.

However, this is only a single indicator. When considering the effectiveness in relation to other indicators, does TISCO really produce effective business or not? By applying the Dupont analysis model to analyze two profitability indicators ROA and ROE and Total assets turnover we have the results as shown in Table 2:

Table 2. Indicators and ratios of ROA, ROS and Total assets turnover ratios

\begin{tabular}{lccc}
\hline Targets & Year 2016 & Year 2017 & Year 2018 \\
\hline ROA & $1.85 \%$ & $1.01 \%$ & $0.27 \%$ \\
ROS & $2.40 \%$ & $1.03 \%$ & $0.26 \%$ \\
Total assets turnover & $76.95 \%$ & $97.85 \%$ & $103.42 \%$ \\
\hline
\end{tabular}

Source: Authors' analysis.

The return on assets (ROA) of TISCO over the years is analyzed in the Dupont model as follows:

Figure 2. Description of ROA and influencing factors

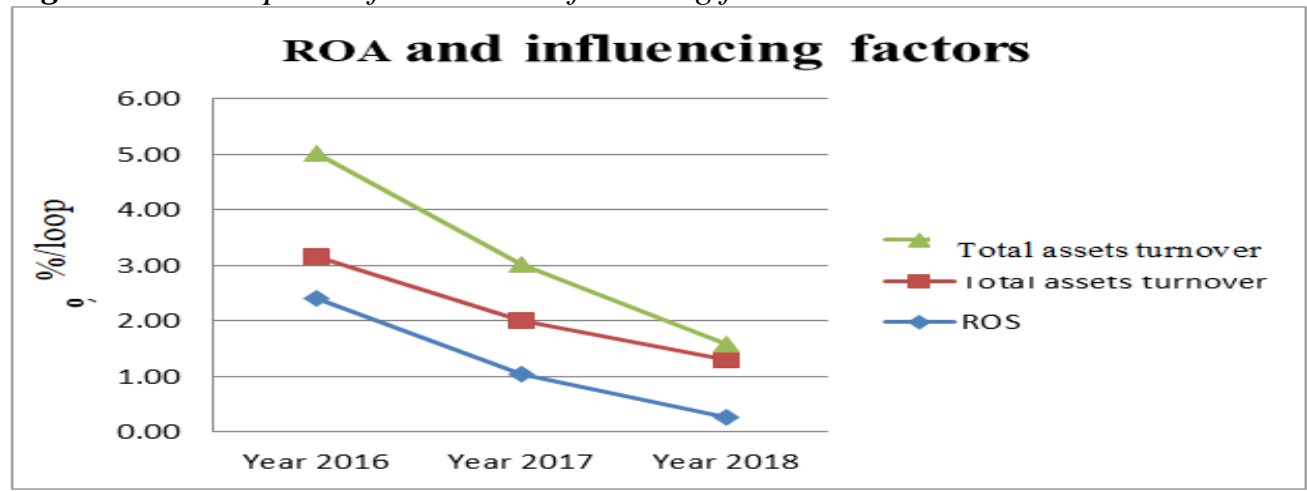

Source: Calculated results by the authors.

Table 2 and Figure 2 show, ROA and ROS of TISCO from 2016-2018 tend to decrease. The main reason was due to the decrease of the company's Total Assets and Equity, although Net Sales and Total Assets Turned Upwards, but these were not significant. This shows that the production and business activities of TISCO are tending to decrease, and the rate of Return on Assets decreases. ROS of TISCO is reduced, so it is possible to comment: TISCO is not competitive, so TISCO needs a reasonable cost management policy, saving costs. From there, it will help increase profit after tax and boost ROS will increase. The analysis also showed that TISCO inefficient use of assets due to ROA significantly reduced. From Table 1, we calculate the target table and the ratio of criteria as follows (Table 3): 
Table 3. Indicators and ratios of ROA, ROE and Financial autonomy ratios

\begin{tabular}{lccc}
\hline Targets & Year 2016 & Year 2017 & Year 2018 \\
\hline ROA & $1.85 \%$ & $1.01 \%$ & $0.27 \%$ \\
ROE & $7.39 \%$ & $5.30 \%$ & $1.55 \%$ \\
Financial autonomy coefficient & $24.98 \%$ & $19.00 \%$ & $17.70 \%$ \\
\hline
\end{tabular}

Source: Authors 'analysis.

In terms of return on equity ROE, according to the Dupont method we will analyze the relationship with the following factors:

Figure 3. Description of ROE and influencing factors

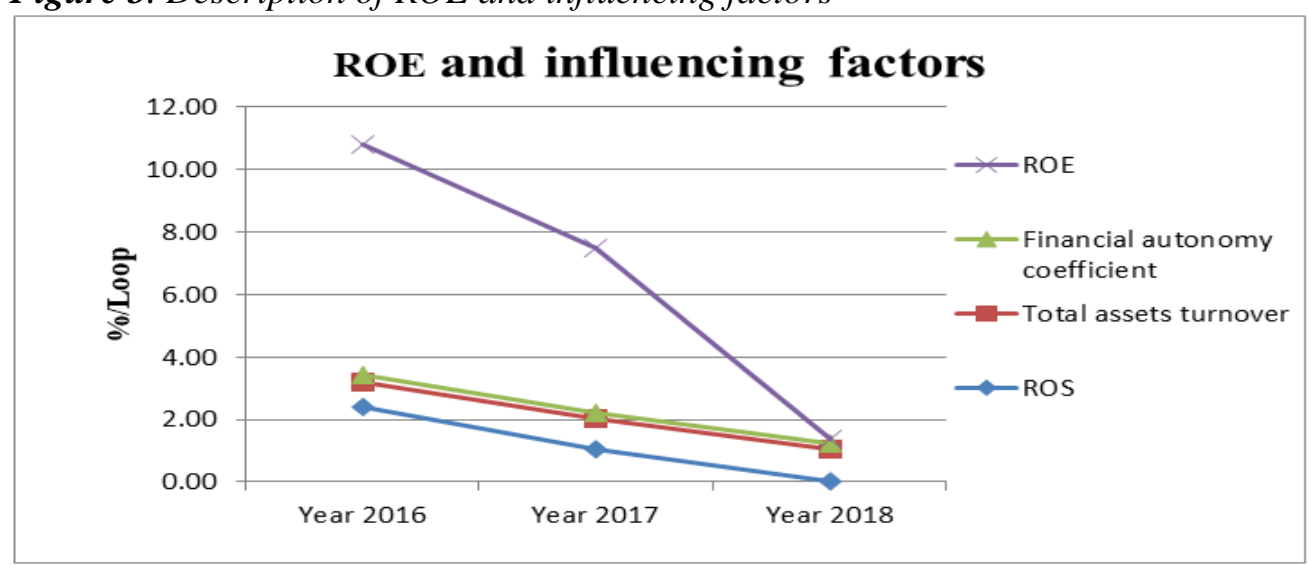

Source: Calculated results of the authors.

From Table 3 and Figure 3, it is shown that the ROE of TISCO in the past 3 years from 2016-2018 has tended to decrease. In 2016, ROE of TISCO reached 7.39\%, by 2018 , it was reduced to only $1.55 \%$. The reason is that this year, both ROS, the Financial autonomy ratio (2016 was $24.98 \%$, in 2018 dropped to $17.70 \%$ ) of TISCO all fell and were at low levels. However, the reduction of equity by TISCO will reduce liabilities in the capital structure to minimize financial risks. This comes to a conclusion that in order to increase the return on ROE, TISCO must increase ROS by saving costs, finding orders with high profitability, increasing asset utilization, and controlling risk when using financial leverage.

\section{Conclusions and Recommendations}

Understanding the financial situation of each business is extremely important, determining the existence and development, helping managers and planners to make the right decisions to ensure production and business activities to achieve high efficiency. TISCO is a large Vietnamese company, producing and trading in iron and steel, in recent years the company has been inefficient. Therefore, in order to objectively and honestly assess the financial situation of TISCO in the period of 2016-2018 and make recommendations to overcome and develop solutions of the company is extremely necessary to be based on well known models as the Dupont. 
The paper conducted the application of Dupont model to analyze ROE and ROA financial indicators at TISCO in order to improve production and business performance of the company. Proposing to the company to be more proactive in strengthening maintenance, expanding business operations, reducing unnecessary costs, improving the efficiency of using resources, solutions to overcome difficulties, bringing revenue and profits soaring every year. Some expenses have not achieved high efficiency such as ROA, ROE, ROS, quick solvency, number of asset turnover, etc. Therefore, in the coming years, the company needs to overcome these limitations.

Based on the analysis of data on the financial situation of TISCO in the period of 2016-2018 based on Dupont model along with financial indicators ROA, ROE, the article offers some proposed solutions to increase the ratio profit and ensure financial safety of TISCO in the future:

- Assets and capital resources: It is necessary to use properties and capital appropriately in the current period, because TISCO has invested a large amount of assets with high asset utilization efficiency compared to many Vietnamese businesses. However, in order to improve the profitability ratio the company needs to use assets more effectively which saves on borrowing costs.

- Regarding the rate of return on revenue: Need to improve the rate of return on revenue, TISCO needs to have new product development strategies as well as marketing strategies to expand the consumption market to increase sales of products.

- Regarding labor resources: With most of the direct production workers being unskilled workers, TISCO needs to have policies to improve skills for employees to contribute to improving labor productivity. Moreover, the working environment has many toxic parts and high working intensity, so it is important to ensure the health and safety for employees of the enterprise, so that employees are assured to work.

- Reduce costs and improve profits: With revenue-cost-profit, if the company wants to achieve high profits, in addition to increasing revenue, it must reduce costs. The problem the company needs to do is to minimize the costs which come from the cost of goods sold always accounting for a high proportion of the cost, the main reason for the decrease in profit. Then find solutions to increase sales and profits.

- The debt ratio: Although the total debt over the years, from 2016-2018 has tended to decrease. Although TISCO has tended to reduce the adjustment to ensure financial security, depending on the situation and its business strategy, the company can balance using this capital appropriately.

\section{References:}

Areeda, Ph.E. 1996. The Socratic method. Harvard Law Review, 109(5). 
Boyd, G. M. 1989. Some suggestions for a "new and improved" DuPont model, Journal of Financial Education, Fall, 29-32.

Christina S.S., Karthikeyan, K. 2012. Financial Performance of Pharmaceutical Industry in India using DuPont Analysis. European Journal of Business and Management, 14(4), 84-91.

Curtis, P., Thalassinos, E.Y. 2005. Equity fund raising and "creative" accounting practices: Indications from Athens Stock Exchange for the 1999-2000 period. European Research Studies Journal, 8(1-2), 127-135.

Heikal, M., Khaddafi, M. 2014 . Influence Analysis of Return on Assets (ROA), Return on Equity (ROE), Net Profit Margin (NPM), Debt To Equity Ratio (DER), and current ratio (CR), Against Corporate Profit Growth In Automotive In Indonesia Stock Exchange. International Journal of Academic Research in Business and Social Sciences, 12(4), 101-114.

Kourtis, E., Kourtis, G., Curtis, P. 2019. An Integrated Financial Ratio Analysis as a Navigation Compass through the Fraudulent Reporting Conundrum: A Case Study. International Journal of Finance, Insurance and Risk Management, 9(1-2), 3-20.

Maranville, S.J., Liesz, J.T. 2008. Ratio analysis featuring the dupont method: an overlooked topic in the finance module of small business management and entrepreneurship courses. Small Business Institute ${ }^{\circledR}$ Journal, 1(1), 17-34.

Prendergast, P. 2006. Financial analysis: how a "modified DuPont approach" to ratio analysis can be used to drill down to the true cause of financial performance problems, Financial Management, P8, 48-49.

Rupeika-Apoga, R., Saksonova, S. 2018. SMEs' Alternative Financing: The Case of Latvia. European Research Studies Journal, 21(3), 43-52, DOI: 10.35808/ersj/1042.

Solovjova, I., Rupeika-Apoga, R., Romanova, I. 2018. Competitiveness Enhancement of International Financial Centres. European Research Studies Journal, 21(1), 5-17, DOI: $10.35808 / \mathrm{ersj} / 925$.

Suharno, P., Dini, I. 2018. The Influence of Work Stress, Working Cost, Compensation and Work Discipline on Employee' Productivity. International Journal of Economics and Business Administration, 6(4), 62-75.

TISCO Financial Statement 2016-2018. Report retrieved from http://www.tisco.com.vn/quan-he-co-dong/bao-cao-tai-chinh.html. 